\title{
Successful rehabilitation of Macronectes halli and Macronectes giganteus in southeastern Brazil
}

\author{
Sucesso na reabilitação de Macronectes halli \\ e Macronectes giganteus no sudeste do Brasil
}

\author{
Natássia Bacco MANNINA ${ }^{1}$; Daniela Magalhães Drummond de MELLO ${ }^{1}$; Rebeca Pires WANDERLEY ${ }^{1}$ \\ ${ }^{1}$ Instituto de Pesquisas Cananéia, Cananéia - SP, Brazil
}

\begin{abstract}
This report describes the successful rehabilitation of two species of pelagic seabirds (Macronectes halli and Macronectes giganteus) rescued on the southern coast of the state of São Paulo, Brazil, and taken to the IPeC rehabilitation center (S$\left.25^{\circ} 023258 \mathrm{~W}-47^{\circ} 928737\right)$. Data on the enclosures, diet, clinical management and laboratory tests were detailed during the $75 \mathrm{~d}$ of treatment, during which the birds remained at the center. This report demonstrates that a combination of environmental and nutritional management with a proper diagnosis and adequate clinical treatment naturally lead to a shorter period in captivity, which is crucial to the successful rehabilitation of these birds. The enclosures should have visual isolation and animals kept separate from other birds. The form of offering food differs based on the feeding habits and taxon. At the time of release back into the wild, the site chosen should be isolated to enable the bird to feel more secure when taking flight. The present report describes the first record of the rehabilitation and release of these two species in Brazil.
\end{abstract}

Keywords: Rehabilitation. Macronectes halli. Macronectes giganteus. Pneumonia. Hypothermia. Pelagic.

\section{Resumo}

Este relato descreve a reabilitação bem-sucedida de duas espécies de aves marinhas pelágicas (Macronectes halli e Macronectes giganteus) resgatadas no litoral sul de São Paulo e levadas ao Centro de Reabilitação IPeC (S- $25^{\circ} 023258$ $\left.\mathrm{W}-47^{\circ} 928737\right)$. As medidas de ambientação dos recintos, dieta, manejo clínico e exames laboratoriais, implementadas nos 75 dias em que as aves permaneceram no Centro, foram detalhadamente descritas. Este relato demonstrou que a combinação de um correto manejo ambiental e nutricional com o diagnóstico e tratamento clínico adequados leva naturalmente à uma brevidade nos dias de cativeiro, todos considerados fatores essenciais para o sucesso na reabilitação dessas aves. Os recintos devem ter isolamento visual, e os animais devem ser mantidos separados de outras aves. A alimentação e a forma de ofertar o alimento variam de acordo com hábitos alimentares e táxon. No momento da soltura, o lugar deve ser isolado, deixando o animal mais seguro para alçar voo. Este relato descreve o primeiro registro de reabilitação e soltura de ambas as espécies no Brasil.

Palavras-chave: Reabilitação. Macronectes halli. Macronectes giganteus. Pneumonia. Hipotermia. Pelágico.

Correspondence to:

Natássia Bacco Mannina

Instituto de Pesquisas Cananéia

Rua Tristão Lobo, 199 - Centro

CEP 11990-000, Cananéia, SP, Brazil

e-mail: nbacco2000@gmail.com

Received: 26/9/2017

Approved: 28/2/2018

The northern giant petrel (Macronectes halli) and southern giant petrel (Macronectes giganteus) belong to the order Procellariiformes and are distributed throughout a sizable portion of the southern hemisphere, including Africa, Antarctica and sub-Antarctic islands (CATARD, 2001;
PATTERSON et al., 2008). The two species are classified as "least concern" on the red list of threatened species of the International Union for Conservation of Nature (IUCN RED LIST OF THREATENED SPECIES, 2016) and are considered sentinel species of environmental conditions, since they remain kilometers from the coast throughout much of their lifetimes (BURGER; GOCHFELD, 2004; CARVALHO et al., 2013) and have the ability to respond physiologically to situations of environmental imbalance (CARVALHO et al., 2013). These birds also provide information on environmental changes on spatial, trophic and temporal scales (TABOR; AGUIRRE, 2004). There are few reports on the management, rehabilitation and 
hematological patterns of these species, which underscores the importance of investigating these aspects whenever the opportunity arises to encounter a living specimen.

The first record of $M$. halli in Brazil was an individual found dead in the region of Ilha Comprida in the state of São Paulo in 1994 (MARTUSCELLI et al., 1995). Soon afterward, two living individuals were found - one in the municipality of Iguape (state of São Paulo) in 1999 and another in the southern portion of the state of Rio Grande do Sul in 2000. Both were taken to rehabilitation centers, but treatment was unsuccessful (BUGONNI et al., 2003). These animals can easily go into shock during handling due to stress stemming from little contact with humans in the natural environment, which can lead to alterations in the physiological state and death (FOWLER, 1999). Thus, some factors are of extreme importance to successful rehabilitation. Management should be performed in a safe, confident manner, with optimization of the time in which the individual is restrained (JANUARY et al., 2012). The diet should be adequate for the species. Enclosures should have the proper conditions to enable the captive animal interaction with the environment as close as possible to its behavior in the wild. Thus, a complex setting should be offered, with visual barriers, areas to perch, etc. (MENDES et al., 2006).

With birds, it is important for captive animals to perform basic functions, such as locomotion, feeding, resting and preening. Moreover, caution should be exercised regarding maintaining a clean, pathogen-free environment to avoid diseases and other problems, such as pododermatitis (CUBAS, 1996).

The aim of the present report is to detail clinical and management procedures conducted during the successful rehabilitation and release of a northern giant petrel (M. halli) and southern giant petrel (M. giganteus) in the region of Ilha Comprida on the southern coast of the state of São Paulo, Brazil.

\section{Case 1}

A sub-adult M. halli was found on Marujá Beach on Cardoso Island (Latitude: -25.24449 Longitude: -48.03114) and taken to the rehabilitation center of the Cananéia Research Institute on June 20, 2016. During the clinical examination, the bird exhibited signs of fatigue, but was alert, weighed $4.350 \mathrm{~kg}$, presented discrete hypothermia (cloacal temperature: $37.5^{\circ} \mathrm{C}$ ), slightly thin (evaluated at the breast), had pale oral mucosa, was dehydrated, had discrete enophthalmia, watery feces, respiratory rales (bubbling and rattling sounds) and intense shortness of breath.

The bird remained in treatment for $35 \mathrm{~d}$, initially in an interior environment for $10 \mathrm{~d}$ with controlled temperature $\left(28\right.$ to $\left.30^{\circ} \mathrm{C}\right)$. At this time, the bird was kept on plastic pallets to avoid contact between the feathers and feces. The environment was cleaned daily, with the substitution of floor paper and disinfection with quaternary ammonium (2\%). The bird was transferred to an enclosure as soon as it exhibited signs of improvement. Throughout the treatment period, three complete blood counts and one microbiological culture (blood agar) of the trachea were performed for the evaluation of health status.

The medications and vitamin supplements described below were determined based on the progression of clinical signs and the bird's behavior. Blood was taken from the ulnar vein one week after admission to the rehabilitation center. Determining the hematological parameters enabled the best guidance of the treatment during the remaining rehabilitation process (Table 1).

Sucralfate $(25 \mathrm{mg} / \mathrm{kg})$ was administrated orally as a heated fluid, changing gradually from $60 \mathrm{ml}$ until reaching $180 \mathrm{ml}$, with electrolytes (oral administration) four times a day and a vitamin supplement (Glicopan ${ }^{\odot} 1 \mathrm{ml}$, Hemolitan ${ }^{\odot}$ $1 \mathrm{ml}$ ) once a day for two days. From the third to the fifth day, fish soup (sardines - Sardinops sagax) was administered (140 $\mathrm{ml}-180 \mathrm{ml}$ ), progressing to the thicker paste four times a day. During this period, a vitamin and mineral supplement (2 $\mathrm{g}$ of Aminomix ${ }^{\oplus}$ once a day) and probiotc ( $1 \mathrm{~g}$ of Organew ${ }^{\oplus}$ once a day) was administered through a feeding tube, along with hydration with electrolytes once a day. On D 6, a diet was implemented with $180 \mathrm{ml}$ of a paste of beef, bovine liver, chicken and a vitamin supplement $(2 \mathrm{~g}$ Aminomix ${ }^{\oplus}$ ) (Figure 1).

Respiratory treatment was initiated on the second day. The trachea was swabbed and an antibiotic (amoxicillin with clavulanate potassium $[125 \mathrm{mg} / \mathrm{kg}]$ ) was administered orally for $7 \mathrm{~d}$. Itraconazole $(25 \mathrm{mg} / \mathrm{kg})$ was administered orally for $20 \mathrm{~d}$. The bird was submitted to two sessions of nebulization with $4 \mathrm{ml}$ of $0.9 \%$ saline solution alternating with either $0.5 \mathrm{ml}$ de gentamicin $(5 \mathrm{mg} / \mathrm{mL})$ or $1.5 \mathrm{ml}$ of acetylcysteine $(22 \mathrm{mg} / \mathrm{mL}$ ) from 20 to $30 \mathrm{~min}$ within a transport box covered with towels to avoid vapor escape. The bird presented intense respiratory distress on the $\mathrm{D} 3$ of treatment and furosemide $(1 \mathrm{mg} / \mathrm{kg})$ and bromhexine $(1.5 \mathrm{mg} / \mathrm{kg})$ were administered intramuscularly for $3 \mathrm{~d}$, with significant improvement observed during subsequent applications. 
On D 12, the bird began to show signs of improvement, supporting itself on the lower limbs with less difficulty. On D 13, the bird regurgitated the fish offered in the morning and the therapeutic measure was the administration of ranitidine $(2.2 \mathrm{mg} / \mathrm{mg}$ ) and a liver protector (silymarin $75 \mathrm{mg} / \mathrm{kg}$ ). On D 16, the bird was transferred to the external enclosure with the following characteristics: sandy ground (previously sterilized with a fire broom) and pallets, protection on the sides with a forged iron screen, mosquito net, transparent plastic tarp around the entire environment and a pool for the bird to bathe itself voluntarily, with areas of sun and shade. Cleaning was performed by removing excess feces and disinfection with quaternary ammonium in spray form. On sunny days, the bird was placed in the $10000-\mathrm{L}$ pool with a visual barrier measuring $1.70 \mathrm{~m}$, where it remained for 10 to $15 \mathrm{~min}$, alternating baths with fresh water and salt water to assist in the maintenance/recovery of the feathers.

From the first day of captivity, the bird was offered several types of animal protein, such as fish, chicken, beef and bovine liver. On D 17 of rehabilitation, the bird fed voluntarily on chicken meat. Beginning at this time, the bird demonstrated greater interest in beef and pieces of meat were offered in two different small sizes (approximately $4 \times 4 \mathrm{~cm}$ and $15 \times 15 \mathrm{~cm}$ ) tied to the pallet with wire, from which the bird was able to pull off and swallow smaller portions. The meat was supplemented with Aminomix ${ }^{\circledast}$ once a day (Figure 2).

Table 1 - Hematological parameters of the two animals after admission in the institution - IpeC laboratory - 2018

\begin{tabular}{|c|c|c|c|c|c|c|}
\hline & \multicolumn{2}{|c|}{ M. giganteus } & \multicolumn{3}{|c|}{ M. halli } & \multirow{2}{*}{ Unit } \\
\hline & July 27, 2016 & August 12, 2016 & July 7, 2016 & July 9, 2016 & July 15, 2016 & \\
\hline Erythrocytes & 2.7 & 3.08 & 3.24 & 2.2 & 2.42 & cells $/ \mu \mathrm{L}$ \\
\hline Hemoglobin & 10.39 & 9.43 & 10.46 & 10.12 & 9.76 & $\mathrm{~g} / \mathrm{dL}$ \\
\hline Hematocrit & 42 & 36 & 39 & 40 & 41 & $\%$ \\
\hline $\mathrm{MCV}$ & 155.55 & 116.88 & 120.37 & 181.82 & 169.42 & $\mathrm{fL}$ \\
\hline MCVC & 24.74 & 26.21 & 26.82 & 24.69 & 23.80 & $\mathrm{~g} / \mathrm{dL}$ \\
\hline $\mathrm{MCH}$ & 38.48 & 30.64 & 28.68 & 42.18 & 40.33 & $\mathrm{pg}$ \\
\hline Leukocytes & 15000 & 12000 & * & 17000 & 13000 & cells/ $\mu \mathrm{L}$ \\
\hline Monocytes & $750(5 \%)$ & $360(3 \%)$ & * & $1020(6 \%)$ & $650(5 \%)$ & cells/ $\mu \mathrm{L}$ \\
\hline Lymphocytes & $5550(37 \%)$ & $2880(24 \%)$ & * & $5950(35 \%)$ & $5070(39 \%)$ & cells/ $\mu \mathrm{L}$ \\
\hline Basophils & $300(2 \%)$ & $120(1 \%)$ & * & 0 & 0 & cells/ $\mu \mathrm{L}$ \\
\hline Eosinophils & $750(5 \%)$ & $840(7 \%)$ & * & $680(4 \%)$ & $650(5)$ & cells/ $\mu \mathrm{L}$ \\
\hline Heterophils & 7650 (51\%) & $7800(65 \%)$ & * & $9350(55 \%)$ & $6630(51 \%)$ & cells/ $\mu \mathrm{L}$ \\
\hline Thrombocytes & 3700 & 195000 & * & 62000 & 63000 & cells $/ \mu \mathrm{L}$ \\
\hline Total proteins & 2.95 & 4.39 & 2.5 & 1.96 & 2.86 & $\mathrm{~g} / \mathrm{dL}$ \\
\hline Glucose & & 355.6 & & & & $\mathrm{mg} / \mathrm{dL}$ \\
\hline
\end{tabular}

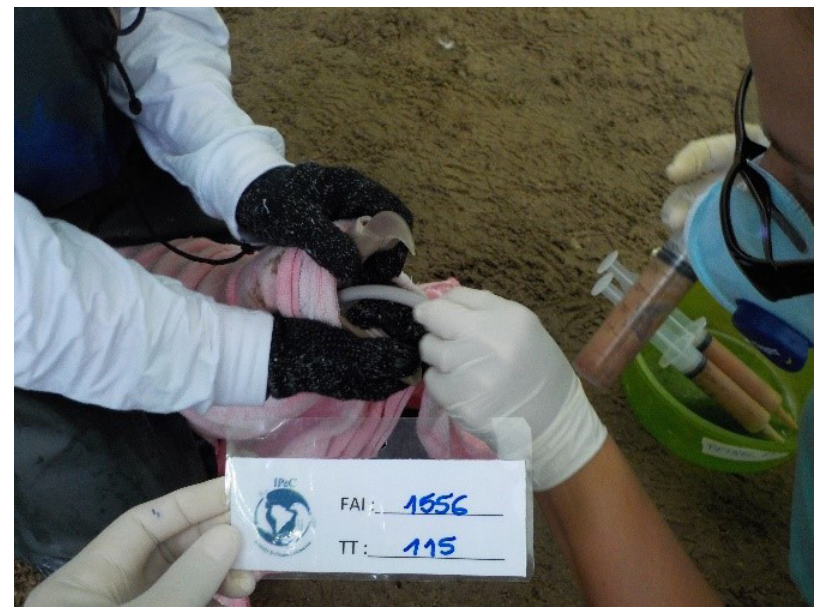

Figure 1 - Esophageal feeding tube with meat paste (Macronectes halli)

Source: IPeC archives

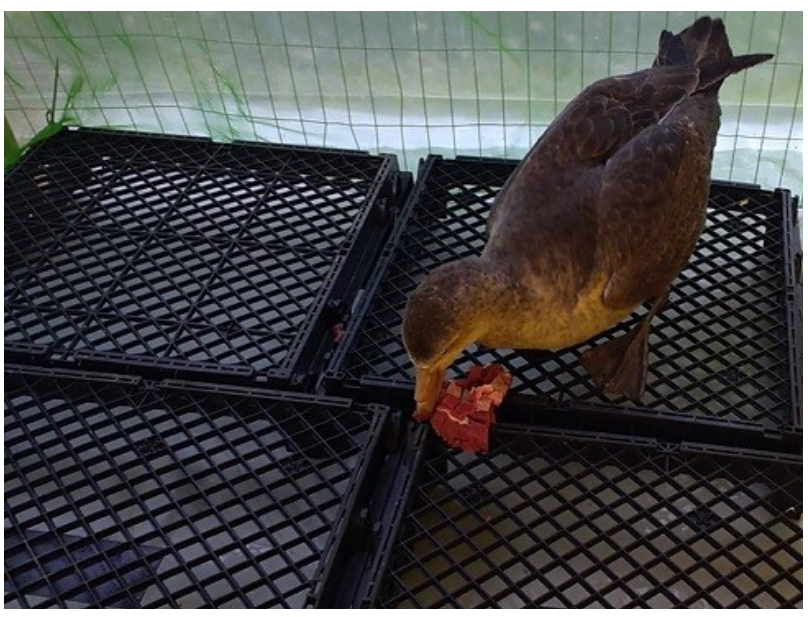

Figure 2 - Bird feeding on beef tied to pallet (Macronectes halli)

Source: IPeC archives 
With the improvement in the clinical condition of the bird, an analysis of the hematological profile, which demonstrated a slight increase in hemotocrit values concomitant to a reduction in the total number of leukocytes (Table 1), greater autonomy in self feeding and water-proofing the feathers as well as an increase in strength during handling and the ability to defend itself and attack, the bird was considered ready to return to its natural environment. One day prior to release, biometrics were performed for some body parts: beak length $=9.8 \mathrm{~cm}$; height of beak at base $=4.2 \mathrm{~cm}$; tarsus length $=9.8$ $\mathrm{cm}$. These measures suggest that the individual was a male (COPELLO et al., 2006; CARLOS; VOISIN, 2008).

The bird was transported to Boqueirão Sul Beach in the municipality of Ilha Comprida (Latitude: -25.028152, Longitude: -47.882239 ) by the team of the rehabilitation center and released on July 24, 2016 at $7 \mathrm{am}$. At the time of release, the ocean was calm and there was no wind ( 0 on the Beaufort scale). When a breeze began ( 1 on the Beaufort scale), the bird ran along the sand on the beach, took flight and headed out to sea. The adjacent beaches were monitored daily, and the bird was not seen again.

\section{Case 2}

A juvenile M. giganteus was rescued in the municipality of Iguape, state of São Paulo (Latitude: -24.74938 Longitude: -47.55166) and was admitted to the rehabilitation center on July 23, 2016. During the clinical examination, the bird presented hypothermia (cloacal temperature: $35.8^{\circ} \mathrm{C}$ ) and malnutrition (as noted at the reduced breast muscles), was alert, but had slow reflexes, weighed $3.70 \mathrm{~kg}$, with pale oral mucosa, severe dehydration and enophthalmia. The bird was initially kept in a closed location on top of a plastic pallet with a folded towel to protect the keel from body pressure on the ground/pallet (Figure 3).

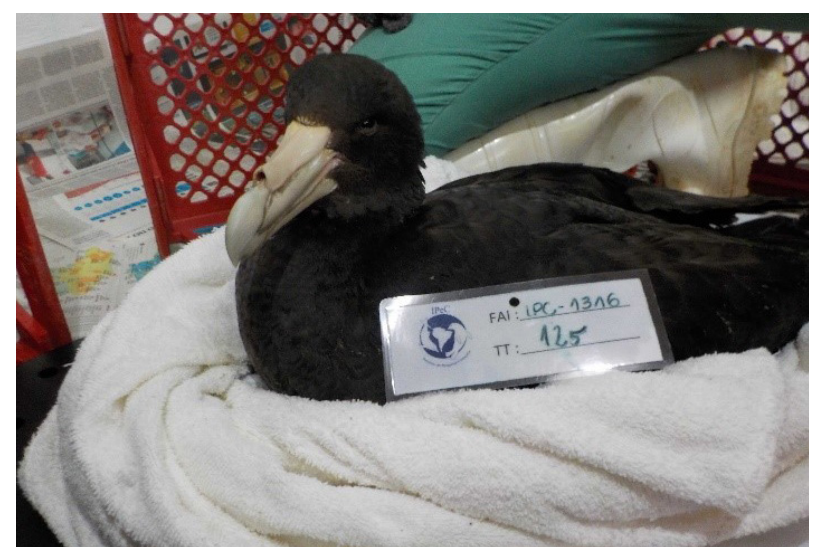

Figure 3 -Bird in quarantine on pallet with towel protecting keel (Macronectes giganteus)

Source: IPeC archives
The management and clinical treatment of both birds were quite similar, except for the administration of medication for the treatment of acute pneumonia, since the respiratory tract of the juvenile M. giganteus had no noteworthy alterations.

On August 1, 2016, treatment with itraconazole (oral administration once a day for $15 \mathrm{~d}$ ) was instituted, as this is an important medication used for the control of fungal infections acquired in captivity. On the same day, the first of the three hematological exams during rehabilitation was performed and a meat paste (same diet as the other individual) was force-fed using an esophageal tube. After $22 \mathrm{~d}$ of rehabilitation, the bird fed voluntarily on pieces of fish (approximately $5 \times 5 \mathrm{~cm}$ ) in the water. On D 23, it also fed voluntarily on pieces of meat (approximately $5 \times 5 \mathrm{~cm}$ ) placed in the water. This feeding pattern was maintained until the time of release. The animal demonstrated no interest at any time for larger pieces of meat tied to the pallet and preferred eating in the water through to the end of treatment (Figure 4). This difference in feeding may be related to the development phase of each individual as well as differences between sexes (HUNTER; BROOKE, 1992).

Most hematological variables were within the ranges reported for M. giganteus in the wild in the Patagonia region of Argentina (UHART et al., 2003). A slight increase in hematocrit values was found, accompanied by practically constant values of total proteins, representing an effective increase in the volume occupied by erythorcytes in the total blood. A reduction in leukocytes also occurred, especially heterophils, indicating a reduction in the innate immune response caused by microbial infection and inflammatory responses (CAPITELLI; CROSTA, 2013). RBC, MCV, $\mathrm{MCVC}$ and thrombocyte values are reported for the first time for this species in the present study.

With the observed improvement in the clinical state, greater autonomy in feeding and water-proofing the feathers, as well as an increase in strength during handling and the ability to defend itself and attack, the bird was considered ready to return to its natural environment. One day prior to release, biometrics were performed for some body parts: beak length $=9.2 \mathrm{~cm}$; height of beak at base $=3.7$ $\mathrm{cm}$; tarsus length $=8.3 \mathrm{~cm}$. These measures suggest that the individual was a male (COPELLO et al., 2006; CARLOS; VOISIN, 2008).

The bird was transported to Boqueirão Sul Beach in the municipality of Ilha Comprida (Latitude: -25.023124, 


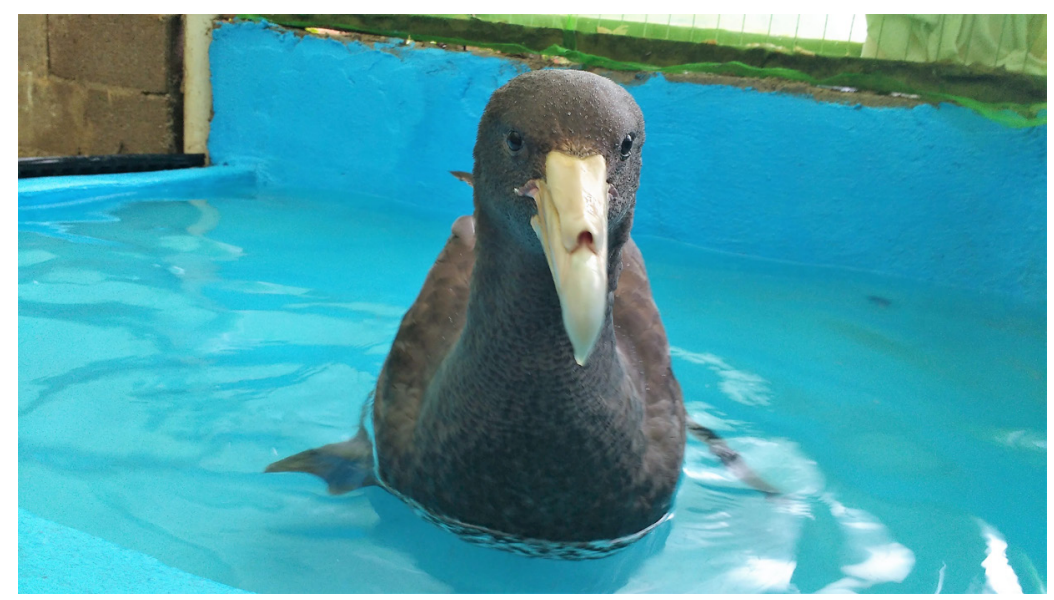

Figure 4 - Bird on water (Macronectes giganteus)

Source: IPeC archives

Longitude: -47.879788) and released on August 31, 2016. At the time of release, the ocean was choppy, with a moderate wind (4 on the Beaufort scale). After leaving the containment/transportation box, the bird remained on the sand for a few minutes, took flight and landed on the water, where it remained for about a minute in the surf. It took flight again and headed out to sea. The team remained at the location until the bird was no longer in sight.

For both species, the offer of several types of food and successful spontaneous feeding was considered essential to minimizing handling and, consequently, stress. Moreover, this was one of the determinant factors for the better results, such as the increase in strength during handling and the ability of the birds to defend themselves and attack in only four days. A study conducted in the state of Rio Grande do Sul (southern Brazil) reports differences in the diet among sexes. Males have more terrestrial habits and prefer to feed on the carcasses of penguins and pinnipeds, whereas females prefer fishes, crustaceans and cephalopods (GONZÁLES-SOLÍS et al., 2000, 2002; GONZÁLEZSOLÍS, 2004). The evaluation of feeding preference and the main biometric measures (beak length, tarsus length and weight) of the individuals agree with the data on sexual dimorphism for both juveniles and adults, demonstrating the likelihood that both individuals were males (COPELLO et al., 2006; CARLOS; VOISIN, 2008).

The blood exams were important to following up the evolution of the clinical condition of the birds and assisted in the decision-making process with regard to the time of release. Some variables were described for the first time for both species. In the fungal culture (Stuart transport medium and Sabouraud agar culture medium) of the trachea from M. halli, no fungal growth was found, whereas the bacterial culture (blood agar medium) demonstrated the growth of Escherichia coli and Enterobacter cloacae. The establishment of these bacteria as significant infections was successfully prevented with the selected antibiotics. Leotta et al. $(2003,2006)$ isolated E. coli from the air sacs and pericardium and Pasteurella multocida using solid agar medium and polymerase chain reaction from several oceanic birds, including M. giganteus, in a colony in Antarctica.

The release of the birds in a more isolated area was important to offering security when taking flight. The lack of wind exerted an influence, delaying the initiative of the $M$. halli individual to take flight. With the release of the M. giganteus individual, even with a moderate wind, the bird was able to take flight in just a few minutes after being released and landed voluntarily on the water where the waves were able to reach it. The choice of the location and environmental conditions were important to the releases, as the birds had spent many days in captivity without flying.

In the final days of treatment, the animals demonstrated attack and defense behaviors, voluntary feeding and short flights within the enclosures, all of which were indicative of healthy individuals. Clinical signs, such as consistent feces with a normal odor, mucosa of normal color, adequate blood findings (UHART et al., 2003) and the absence of respiratory problems and fatigue during the activities demonstrated that the birds were ready to be released.

\section{Acknowledgments}

The authors are grateful to the Marine Animal Rehabilitation Center of the Cananéia Research Institute for funding and infrastructural support as well as the entire team involved. 


\section{References}

BUGONI, L.; NEVES, T. S.; CORRADO, A.; OLMOS, A. F.; BARQUETE, V. Northern Giant Petrels Macronectes halli in Brazil. Atlantic Seabirds, v. 5, n. 3, p. 127-129, 2003.

BURGER, J.; GOCHFELD, M. Marine birds as sentinels of environmental pollution. EcoHealth, v. 1, n. 3, p. 263-274, 2004. doi: 10.1007/s10393-004-0096-4.

CAPITELLI, R.; CROSTA, L. Overview of psittacine blood analysis and comparative retrospective study of clinical diagnosis, hematology and blood chemistry in selected psittacine species. Veterinary Clinics of North America: Exotic Animal Practice, v. 16, n. 1, p. 71-120, 2013. doi: 10.1016/j.cvex.2012.10.002.

CARLOS, C. J.; VOISIN, J.-F. Identifying giant petrels, Macronectes giganteus and M. halli, in the field and in the hand. Seabird, v. 21, p. 1-15, 2008.

CARVALHO, P. C.; BUGONI, L.; MCGILL, R. A. R.; BIANCHINI, A. Metal and selenium concentrations in blood and feathers of petrels of the genus Procellaria. Environmental Toxicology and Chemistry, v. 32, n. 7, p. 1641-1648, 2013. doi: 10.1002/etc.2204.

CATARD, A. French southern territories. In: FISHPOOL, L. D. C.; EVANS, M. I. Important bird areas in Africa and associated islands. Cambridge: BirdLife International, 2001. v. 11. p. 337-348.

COPELlO, S.; QUINTANA, F.; SOMOZA, G. Sex determination and sexual size-dimorphism in Southern Giant-Petrels (Macronectes giganteus) from Patagonia, Argentina. Emu: Austral Ornithology, v. 106, n. 2, p. 141-146, 2006. doi: 10.1071/MU05033.

CUBAS, Z. S. Special challenges of maintaining wild animals in captivity in South America. Revue Scientifique et Technique (International Office of Epizootics), v. 15, n. 1, p. 267-287, 1996. doi: 10.20506/rst.15.1.918.

FOWLER, G. S. Behavioral and hormonal responses of Magellanic penguins (Spheniscus magellanicus) to tourism and nest site visitation. Biological Conservation, v. 90, n. 2, p. 143-149, 1999. doi: 10.1016/S0006-3207(99)00026-9.
GONZÁLEZ-SOLÍS, J. Sexual size dimorphism in northern giant petrels: ecological correlates and scaling. Oikos, v. 105, n. 2, p. 247-254, 2004. doi: 10.1111/j.0030-1299.2004.12997.x.

GONZÁLEZ-SOLÍS, J.; CROXALL, J.; BRIGGS, D. Activity patterns of giant petrels, Macronectes spp., using different foraging strategies. Marine Biology, v. 140, n. 1, p. 197-204, 2002. doi: $10.1007 / \mathrm{s} 002270100684$.

GONZÁLEZ-SOLÍS, J.; CROXALL, J. P.; WOOD, A. G. Foraging partitioning between giant petrels Macronectes spp. and its relationship with breeding population changes at Bird Island, South Georgia. Marine Ecology Progress Series, v. 204, p. 279-288, 2000. doi: 10.3354/meps204279.

HUNTER, S.; BROOKE, M. L. The diet of giant petrels Macronectes spp. at Marion Island, Southern Indian Ocean. Colonial Waterbirds, v. 15, n. 1, p. 56-65, 1992. doi: 10.2307/1521354.

IUCN RED LIST OF THREATENED SPECIES. Cambridge: IUCN, 2016-3.

JANUARY, O. B.; CORSIGLIA, L.; MASVIDAL, V.; MERRICK, M.; RIGGS, S. M. An introduction to aquatic bird rehabilitation. Arcata: Bird Ally X, 2012. 152 p.

LEOTTA, G. A.; CHINEN, I.; VIGO, G. B.; PECORARO, M.; RIVAS, M. Outbreaks of avian cholera in hope bay, Antarctica. Journal of Wildlife Diseases, v. 42, n. 2, p. 259-270, 2006. doi: 10.7589/0090-3558-42.2.259.

LEOTTA, G. A.; RIVAS, M.; CHINEN, I.; VIGO, G. B.; MOREDO, F. A.; CORIA, N.; WOLCOTT, M. J. Avian cholera in a southern giant petrel (Macronectes giganteus) from Antarctica. Journal of Wildlife Diseases, v. 39, n. 3, p. 732-735, 2003. doi: 10.7589/0090-3558-39.3.732.

MARTUSCELLI, P.; OLMOS, F.; SILVA, R. S. First record of the Northern Giant Patrel Macronectes halli for Brazilian Waters. Bulletin British Ornithologists' Club, v. 115, p. 187-188, 1995.

MENDES, F. R.; NAPOLI, R. P.; MIKICH, S. B. Manejo, reabilitação e soltura de mamíferos selvagens. Arquivos de Ciências Veterinárias e Zoologia da Unipar, v. 9, n. 2, p. 105-109, 2006. doi: 10.25110/arqvet.v9i2.2006.351. 
PATTERSON, D. L.; WOEHLER, E. J.; CROXALL, J. P.; COOPER, J.; PONCET, S.; PETER, H. U.; HUNTER, S.; FRASER, W. R. Breeding distribution and population status of the northern giant petrel Macronectes halli and the southern giant petrel M. giganteus. Marine Ornithology, v. 36, n. 2, p. 115-124, 2008.

TABOR, G. M.; AGUIRRE, A. A. Ecosystem health and sentinel species: adding an ecological element to the proverbial 'canary in the mineshaft'. EcoHealth, v. 1, n. 3, p. 226-228, 2004. doi: 10.1007/s10393-004-0092-8.

UHART, M. M.; QUINTANA, F.; KARESH, W. B.; BRASELTON, W. E. Hematology, plasma biochemistry, and serosurvey for selected infectious agents in southern giant petrels from Patagonia, Argentina. Journal of Wildlife Diseases, v. 39, n. 2, p. 359-365, 2003. doi: 10.7589/00903558-39.2.359. 